\title{
Öryggi sjúklinga - forysta og virk pátttaka lækna er nauðsyn
}

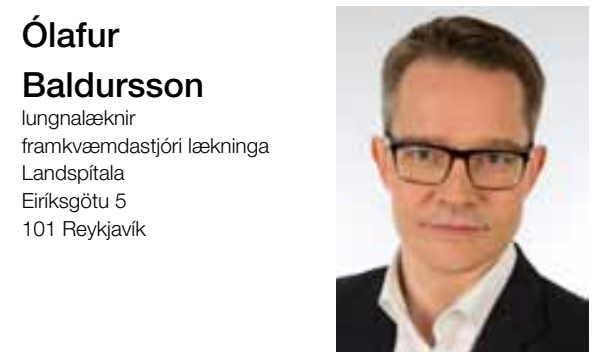

olafbald@landspitali.is

Pó svo að sjúkrahús gæti almennt vel að öryggismálum, sýna rannsóknir að öryggi sjúklinga er ekki eins mikið og talið var og brestir hafa komið í ljós, meðal annars á peim sjúkrahúsum á Vesturlöndum sem við viljum bera okkur saman við. Fyrirliggjandi gögn sýna að tíðni alvarlegra frávika í meðferðum á Landspítala virðist vera svipuð og á pessum sjúkrahúsum. Vandinn er alpjóðlegur, en reynslan hefur sýnt að forysta og virk pátttaka lækna í gæða- og öryggismálum sjúkrahúsa er nauðsynleg til árangurs.

Langvinnur niðurskurður fjárheimilda til Landspítala, að viðbættu efnahagshruni 2008, knúði stjórn og starfsmenn spítalans til pess að huga enn nánar að öryggi sjúklinga en áður hafði tíðkast. Frá pessum tíma hafa ýmis verkefni verið sett af stað með áherslu á að draga úr eða útrýma rangri lyfjameðferð, spítalasýkingum, byltum og fleiru. Mörg pessara verkefna hafa skilað árangri og eru nú eðlilegur hluti af daglegri starfsemi, en að auki hafa ýmis tölvukerfi og ferlar verið bætt. Með straumlínustjórnun (LEAN) hefur einnig tekist að gera ferla og pjónustu skilvirkari og öruggari en áður. Ábendingar frá sjúklingum og aðstandendum berast nú bæði í gegnum ábendingahnapp á heimasíðu spítalans og í árlegri pjónustukönnun. Umbótagildið er ótvírætt. Kerfisbundin skráning frávika (atvikaskráning) og markviss rótargreining (root cause analysis) og úrvinnsla peirra, nýtast til að tryggja stöðugar umbætur, sem er nauðsynlegt pegar sjúklingar streyma til spítalans allan sólarhringinn. Komi öryggisbrestur í ljós er brýnt að greina vandann og lagfæra hann sem fyrst til pess að vernda pá fjölmörgu sjúklinga sem á eftir koma.

En ferlar duga skammt án vandaðra samskipta og opinnar öryggismenningar. Læknar pekkja vel mikilvægi pess að segja sjúklingum og aðstandendum skýrt og greinilega frá fylgikvillum. Hvað Landspítala varðar er lögð áhersla á að öll alvarleg atvik (sbr. lög um landlækni) séu tilkynnt án tafar til framkvæmdastjóra lækninga sem sér um samskipti við Landlæknisembættið í samvinnu við yfirlækna. Unnið er að eflingu menningar sem einkennist af jákvæðum, hreinskilnum og heiðarlegum samskiptum, og er laus við skömm og vömm. Með henni eru allir hvattir til pess að gera grein fyrir eigin mistökum og annarra og til pess að leggja fram tillögur til umbóta, án dómhörku. Petta reynist okkur flestum erfitt og tekur langan tíma að læra, sérstaklega á vinnustað par sem verkefnið er líf fólks og heilsa. Á Landspítala er pessi menningarvakning smám saman að breytast í vegferð. Pau erlendu sjúkrahús sem náð hafa bestum árangri, hafa yfir 10 ára vegferð að baki og hafa rutt úr vegi margskonar hindrunum. Landspítalinn er lagður af stað, ákveðinn í að læra af peim bestu. Hindranirnar eru hins vegar margvíslegar, allt frá húsnæði spítalans sem er löngu úrelt, yfir í að lögregla og dómskerfi eru óvön að fást við mál af pessu tagi. Að auki er fjölmiðlaumræðan talsvert snúin við pessar aðstæður. Sú ákvörðun okkar að opna umræðuna innan og utan spítalans er forsenda umbóta, en hún býður vissulega upp á æsifréttir í stað upplýstrar umræou. Slíkt eykur hættuna á að starfsfólk hiki við að koma á framfæri upplýsingum um frávik, með alvarlegum afleiðingum fyrir pá sjúklinga sem á eftir koma. Meginmarkmiðið verður alltaf að koma í veg fyrir frávik, en pað verður aðeins gert með aðgerðum sem stefna fram í tímann, hvort sem pær ná til nokkurra ára eða til eins dags í senn.

Hvað daglega árvekni varðar hefur svokallað stöðumat verið tekið upp á nokkrum deildum Landspítala. Aðferðin byggir á að- stæðuvitund (situational awareness) sem er notuð í vaxandi mæli í hvers kyns áhættustarfsemi, svo sem í flugrekstri og í verksmiðjum sem fást við hættuleg efni. Á hverri sjúkradeild koma starfsmenn saman í nokkrar mínútur og fara kerfisbundið yfir nokkurs konar tékklista deildarinnar fyrir daginn. Petta er gjarnan gert standandi og ekki er um hefðbundinn fund að ræða. Аðferðin hefur pegar reynst fyrirbyggjandi, og verður innleidd á spítalanum á næstu mánuðum.

Sé litið til lengri tíma blasa við tvö stór verkefni sem eru forsenda áframhaldandi umbóta en pað eru mönnun og húsnæðismál. Unnið er að mönnunarmálum en húsnæðismál Landspítala virðast hins vegar svífa í tómarúmi um pessar mundir. Раð er grafalvarlegt og parf frekari umfjöllun. Í ljósi vinnuálags á lækna parf að kanna hvernig tengja megi gæða- og öryggismál með skýrari hætti við kjarasamninga, bæði til pess að vinnuálag komi ekki niður á sjúklingum og til pess að leita leiða til að umbuna læknum sérstaklega fyrir pau verk sem efla öryggi sjúklinga.

Baráttan fyrir öruggara heilbrigðiskerfi er skammt á veg komin og parf mjög á stuðningi alls samfélagsins að halda. Forysta og breið pátttaka lækna í pessari vegferð er peim og samfélaginu afar nauðsynleg.

\section{Heimildir}

1. To Err is Human: Building a safer health system. Institute of medicine, Bandaríkin 1999.

2. Lög um landlækni nr. 41/2007.

3. National advisory group on the safety of patients in England. Improving the safety of patients in England (Berwick report). gov.uk/government/publications/berwick-review-into-patient-safety - ágúst 2013.

4. Weick KE, Sutcliffe KM. Managing the unexpected: Assuring high performance in the age of complexity. Jossey-Bass, San Francisco 2001.

Patient safety - physician leadership and active participation is essential

Ólafur Baldursson MD, PhD Internist/Pulmonologist Chief Medical Executive Landspítali - The National University Hospital of Iceland 